\title{
Towards an Organizational Economics of Heterogeneous Capabilities
}

\author{
Foss, Nicolai J.
}

Document Version

Final published version

Publication date:

2013

License

CC BY-NC-ND

Citation for published version (APA):

Foss, N. J. (2013). Towards an Organizational Economics of Heterogeneous Capabilities. Institut for Strategic Management and Globalization. SMG Working Paper No. 9/2013

Link to publication in CBS Research Portal

\footnotetext{
General rights

Copyright and moral rights for the publications made accessible in the public portal are retained by the authors and/or other copyright owners and it is a condition of accessing publications that users recognise and abide by the legal requirements associated with these rights.

Take down policy

If you believe that this document breaches copyright please contact us (research.lib@cbs.dk) providing details, and we will remove access to the work immediately and investigate your claim.
}

Download date: 26. Apr. 2023 
TOWARDS AN ORGANIZATIONAL ECONOMICS

OF HETEROGENEOUS CAPABILITIES

Nicolai J. Foss

SMG WP 9/2013

September, 2013 
SMG Working Paper No. 9/2013

September, 2013

ISBN: 978-87-91815-91-1

Department of Strategic Management and Globalization Copenhagen Business School

Kilen, Kilevej 14A

2000 Frederiksberg

Denmark

www.cbs.dk/smg 


\title{
TOWARDS AN ORGANIZATIONAL ECONOMICS
}

\section{OF HETEROGENEOUS CAPABILITIES}

\author{
Nicolai J Foss \\ Department of Strategic Management and Globalization \\ Copenhagen Business School; Kilevej 14, $2^{\text {nd }}$ floor \\ 2000 Frederiksberg; Denmark \\ njf.smg@cbs.dk \\ and \\ Department of Strategy and Management \\ Norwegian School of Economics and Business Administration \\ Breiviksveien 40, N-5045 \\ Bergen; Norway
}

(Invited paper, International Journal of the Economics of Business, Forum on "The Economics of Business: Perspectives on Research").

\begin{abstract}
The notion of "capability" has long been influential in management research as an approach to address firm-level heterogeneity and heterogeneity in competitive outcomes. I discuss how recent advances in economics may allow for a more rigorous understanding and measurement of capability that take organizational practices into account. However, economists may also learn from work on capabilities in management research.
\end{abstract}

Keywords: Organizational capability, productivity, internal organization, organizational economics

JEL Codes: D23, D24, L25, M12 


\section{INTRODUCTION}

As befits a contribution to a journal dedicated to the economics of business, I intend to discuss a notion that has become a central construct in management research from an economics perspective. The notion is that of firm-level "capability," which was coined by George Richardson (1972), acquired a central explanatory role in evolutionary economics (Nelson \& Winter, 1972), and has become the cornerstone of much of strategic management thinking. Thus, strategy's dominant perspective, the resource-based view, and its many relatives and offspring trace the foundations of competitive advantage to capabilities, that is, capabilities are analyzed as antecedents to competitive heterogeneity (Barney, 1991). Economists have also invoked with the construct as a useful shorthand for capturing firm-specific knowledge and intra-industry heterogeneity without, however, making serious attempts to get an analytical grip on it (e.g., Holmström and Roberts, 1998).

However, recent advances in economics with respect to showing the presence of (massive) intra-industry heterogeneity (as summarized in Syverson, 2011), and the actual measurement of the firm-specific causes of such heterogeneity (Bloom and Van Reenen, 2007) imply that economists may not only take capability seriously as a meaningful construct, but may also begin to apply their tools, such as contract theory, to unpacking it. In the process, economists are likely to learn valuable lessons from management scholars.

\section{EXPLAINING CAPABILITY}

\section{Overcoming the Machlup Legacy}


In his Presidential Address to the American Economic Association, Fritz Machlup (1967) famously presented a case that economists should not care about the specificities (e.g., internal organization) of individual firms, as this was unlikely to bring substantial additional insight in the market outcomes that were the real objects of interests for economists. Thus, for the purposes of price theory, firms within an industry could essentially be taken to be homogenous. Somewhat surprisingly, Machlup's view was also reflected in much of the micro-economics of the firm, not just in the standard Marshallian approach, but also in later contract theoretic and transaction cost approaches. While contract theory and transaction cost insights are surely capable of contributing to the understanding of firm heterogeneity (cf. Argyres et al., 2012), explaining such heterogeneity per se has never been a central explanatory task of these approaches (Legros and Newman, 2013). However, while the Machlup view was still holding sway among economists (well into the 1990s), dissenting economists and management scholars highlighted that heterogeneity among firms could be understood in terms of differential capability — an idea that helped them to explain firm boundaries (Richardson, 1972; Langlois and Foss, 1999), competitive heterogeneity in a population of firms (Nelson and Winter, 1982), and competitive advantage (Barney, 1991).

However, the capability construct has mainly been a building block in the analysis on such phenomena, and perhaps for this reason management scholars have been less successful with respect to precisely characterizing capability and its dynamics in terms of the actions and interactions of individuals within firms. Thus, while management research has done much to advance the notion of intra-industry heterogeneity, it may have been less forthcoming with respect to theorizing the antecedents of such heterogeneity, at least in ways that would be appealing to an economist (Argyres at al., 2012). Most work on such antecedents has highlighted cognitive variables, such as managerial cognition and absorptive capacity, and variables related to skill levels and the efficiency of routines. Surprisingly, virtually no work in management research has linked 
differential capability to organizational design (e.g., the structures of communication, delegation, and incentives) or even to the human capital characteristics of firms' workforces.

\section{Recent Economics and the Capabilities Construct}

In most uses of the construct, "firm capability" refer to the efficiency level at which productive activities are carried out, or simply, "firm-level productivity" (e.g., Nelson and Winter, 1982). Recent work in empirical economics (summarized by Syverson, 2011) documents not only massive but also persistent productivity differences between firms in several countries, even within narrowly defined industries. Industrial organization and labor market economists have examined many different antecedents of such differences, including human capital characteristics, firmspecific sunk costs, and differential access to technology spill-overs, usually being able to make use of register data, the traditionally preferred data sources of academic economists.

In contrast, excepting single-firm insider econometrics studies, most research on firm-level productivity has not considered organizational design as a factor explicitly contributing to firmlevel productivity. The reason arguably has to do with the fact that very little publicly available register data contains information on design variables, coupled with economists' traditional skepticism of survey-data. However, work by particularly Nicholas Bloom and John Van Reenen (e.g., 2007; Bloom, Sadun, and Van Reenen, 2012) has, however, successfully demonstrated the explanatory success of rigorous interview-based surveys, particularly when such work can be linked to field-experiments. Their line of research has documented massive productivity differences across firms and public organizations that are to a high extent explainable in terms of the efficiency of the applied management practices as well as ownership patterns.

While this line of research is highly promising, so far it has only identified a subset of the firm-specific determinants of capability/firm-level sources of productivity differences. Thus, it is mainly focused on human resource management practices, to the neglect of such traditional 
organizational design variables as delegation, departmentalization, specialization, and formal communication structures, many of which are theorized in the economics of organization. A further problem is that it tends to approach practices in a partial way, where changing one organizational practices directly leads to productivity improvements, and potentially improvements of profitability. Given this, it is not clear why such practices are not just changed. However, organizational design theory in management research as well as the notion of (Edgeworth) complementarity suggest that elements of organizational design cluster in bundles of discrete practices that are linked to each other in terms of, more or less binding, relations of complementarity. Given this, practices only have a significant performance effect when they are implemented (changed) as a discrete bundle, which is likely to be risky and costly. Moreover, the way in which such practices cluster may reflect not just complementarity, but also a high degree of firm-specificity (Williamson, 1996). These characteristics contribute to the understanding of why differences in performance tend to be sustained within industries (Syverson, 2011).

Finally, while much of the creation of capability may be a matter of learning-by-doing processes, discrete investments in physical assets, location, training and so on clearly also play a role. Organizational economists have made significant strides forward in the understanding of the optimal governance of such investments (Williamson, 1996), which suggests that economists may usefully turn the tools of contracts economics and related fields to the study of capabilities (Argyres et al., 2012).

\section{CONCLUSIONS}

Almost three decades ago, Milgrom and Roberts (1988: 450) suggested that incentive theory had "been made to carry too much of the weight in the theory of organizations. We expect competing

and complementary theories to emerge - theories that are founded on economizing on bounded rationality and that pay more attention to changing technology or to evolutionary considerations." In 
many ways, capabilities theories in management research may be seen as such "competing and complementary theories," and after a long period of neglect on the part of economists, key insights associated with capabilities theories are now being taken seriously by economists. Thus, the capabilities construct serves the purpose of reminding economists of taking firm-level heterogeneity more seriously, and it points to the potential role that such heterogeneity may play in shaping economic organization and competitive outcomes.

Management scholars have for a long time been engaged in serious thinking on some of the factors that shape capability over time and have examined the outcomes of differential capability. I have argued that recent advances in economics may provide a much-needed new set of empiricallygrounded insights in the causes of heterogeneous capability. The capabilities approach to firms will no doubt prosper as a result of economists' skills at model-building and econometric identification. At the same time, economists could do worse than heeding the management arguments that capabilities also depend on bounded rationality, managerial and organizational cognition, and the allocation of attention within a hierarchy. It is, after all, bounded rational managers who (imperfectly) search in a space of available managerial technology and implement such technology, and undertake the investments that contribute to differential capability. Similarly, management scholars with a social-psychology or sociology background have done much to theorize the implicit, relations contracts (i.e., "psychological contracts") that arise in firms, and such contracts also arguably have a strong bearing on the understanding of firm heterogeneity (cf. Gibbons and Henderson, 2012). At any rate, heterogeneous capability is a key example of an important topic on which management scholars and economists can sustain a mutually beneficial discussion.

\section{REFERENCES}

Argyres, N., Felin, T., Foss, N.J. and Zenger, T. 2012. The Organizational Economics of Organizational Capability: a Research Agenda. Organization Science 23: 1213-1226. 
Barney, J.B. 1991. Firm Resources and Sustained Competitive Advantage. Journal of Management 17: 99-120.

Bloom, N. and Van Reenen, J. 2007. Measuring and explaining management practices across firms and countries. Quarterly Journal of Economics, 122: 1351-1408.

Bloom, N., Sadun, R. and Van Reenen, J. 2012. The organization of firms across countries. Quarterly Journal of Economics, 127: 1663-1705.

Gibbons, R. and Henderson, R. 2012. Relational Contracts and Organizational Capabilities Organization Science 23: 1350-1364.

Holmström, B. and Roberts, J. 1998. The Boundaries of the Firm Revisited. Journal of Economic Perspectives 12: 73-94.

Langlois, R.N. and Foss, N.J. 1999. Capabilities and Governance: the Rebirth of Production in the Theory of Economic Organization. KYKLOS 52: 201-218.

Legros, P. and Newman, A. 2013. Contracts, Ownership, and Industrial Organization: Past and Future. Working Paper.

Machlup, F. 1967. Theories of the Firm: Marginalist, Behavioralist, Managerial. American Economic Review 57: 1-33.

Milgrom, P. and Roberts. 1988. Economic Theories of the Firm: Past, Present, and Future. Canadian Journal of Economics, 21: 444-458.

Nelson, R.R. and Winter, S.G. 1982. An Evolutionary Theory of Economic Change. (Cambridge, MA: The Belknap Press).

Richardson., G.B. 1972. The Organisation of Industry. Economic Journal 82: 883-896.

Syverson, C. 2011. What Determines Productivity? Journal of Economic Literature 49: 326-65.

Williamson, O.E. 1996. The Economic Institutions of Capitalism. New York: Oxford University Press. 


\section{SMG - Working Papers \\ www.cbs.dk/smg \\ 2003}

2003-1: Nicolai J. Foss, Kenneth Husted, Snejina Michailova, and Torben Pedersen: Governing Knowledge Processes: Theoretical Foundations and Research Opportunities.

2003-2: Yves Doz, Nicolai J. Foss, Stefanie Lenway, Marjorie Lyles, Silvia Massini, Thomas P. Murtha and Torben Pedersen: Future Frontiers in International Management Research: Innovation, Knowledge Creation, and Change in Multinational Companies.

2003-3: Snejina Michailova and Kate Hutchings: The Impact of In-Groups and OutGroups on Knowledge Sharing in Russia and China CKG Working Paper.

2003-4: Nicolai J. Foss and Torben Pedersen: The MNC as a Knowledge Structure: The Roles of Knowledge Sources and Organizational Instruments in MNC Knowledge Management CKG Working Paper.

2003-5: Kirsten Foss, Nicolai J. Foss and Xosé H. Vázquez-Vicente: “Tying the Manager's Hands": How Firms Can Make Credible Commitments That Make Opportunistic Managerial Intervention Less Likely CKG Working Paper.

2003-6: Marjorie Lyles, Torben Pedersen and Bent Petersen: Knowledge Gaps: The Case of Knowledge about Foreign Entry.

2003-7: Kirsten Foss and Nicolai J. Foss: The Limits to Designed Orders: Authority under "Distributed Knowledge" CKG Working Paper.

2003-8: Jens Gammelgaard and Torben Pedersen: Internal versus External Knowledge Sourcing of Subsidiaries - An Organizational Trade-Off.

2003-9: Kate Hutchings and Snejina Michailova: Facilitating Knowledge Sharing in Russian and Chinese Subsidiaries: The Importance of Groups and Personal Networks Accepted for publication in Journal of Knowledge Management.

2003-10: Volker Mahnke, Torben Pedersen and Markus Verzin: The Impact of Knowledge Management on MNC Subsidiary Performance: the Role of Absorptive Capacity CKG Working Paper.

2003-11: Tomas Hellström and Kenneth Husted: Mapping Knowledge and Intellectual Capital in Academic Environments: A Focus Group Study Accepted for publication in Journal of Intellectual Capital CKG Working Paper.

2003-12: Nicolai J Foss: Cognition and Motivation in the Theory of the Firm: Interaction or "Never the Twain Shall Meet"? Accepted for publication in Journal des Economistes et des Etudes Humaines CKG Working Paper.

2003-13: Dana Minbaeva and Snejina Michailova: Knowledge Transfer and Expatriation Practices in MNCs: The Role of Disseminative Capacity.

2003-14: Christian Vintergaard and Kenneth Husted: Enhancing Selective Capacity Through Venture Bases. 


\section{4}

2004-1: Nicolai J. Foss: Knowledge and Organization in the Theory of the Multinational Corporation: Some Foundational Issues

2004-2: Dana B. Minbaeva: HRM Practices and MNC Knowledge Transfer

2004-3: Bo Bernhard Nielsen and Snejina Michailova: Toward a Phase-Model of Global Knowledge Management Systems in Multinational Corporations

2004-4: Kirsten Foss \& Nicolai J Foss: The Next Step in the Evolution of the RBV: Integration with Transaction Cost Economics

2004-5: Teppo Felin \& Nicolai J. Foss: Methodological Individualism and the Organizational Capabilities Approach

2004-6: Jens Gammelgaard, Kenneth Husted, Snejina Michailova: Knowledge-sharing Behavior and Post-acquisition Integration Failure

2004-7: Jens Gammelgaard: Multinational Exploration of Acquired R\&D Activities

2004-8: Christoph Dörrenbächer \& Jens Gammelgaard: Subsidiary Upgrading? Strategic Inertia in the Development of German-owned Subsidiaries in Hungary

2004-9: Kirsten Foss \& Nicolai J. Foss: Resources and Transaction Costs: How the Economics of Property Rights Furthers the Resource-based View

2004-10: Jens Gammelgaard \& Thomas Ritter: The Knowledge Retrieval Matrix: Codification and Personification as Separate Strategies

2004-11: Nicolai J. Foss \& Peter G. Klein: Entrepreneurship and the Economic Theory of the Firm: Any Gains from Trade?

2004-12: Akshey Gupta \& Snejina Michailova: Knowledge Sharing in Knowledge-Intensive Firms: Opportunities and Limitations of Knowledge Codification

2004-13: Snejina Michailova \& Kate Hutchings: Knowledge Sharing and National Culture: A Comparison Between China and Russia

\section{5}

2005-1: Keld Laursen \& Ammon Salter: My Precious - The Role of Appropriability Strategies in Shaping Innovative Performance

2005-2: Nicolai J. Foss \& Peter G. Klein: The Theory of the Firm and Its Critics: A Stocktaking and Assessment

2005-3: Lars Bo Jeppesen \& Lars Frederiksen: Why Firm-Established User Communities Work for Innovation: The Personal Attributes of Innovative Users in the Case of Computer-Controlled Music

2005-4: Dana B. Minbaeva: Negative Impact of HRM Complementarity on Knowledge Transfer in MNCs

2005-5: Kirsten Foss, Nicolai J. Foss, Peter G. Klein \& Sandra K. Klein: Austrian Capital 
Theory and the Link Between Entrepreneurship and the Theory of the Firm

2005-1: Nicolai J. Foss: The Knowledge Governance Approach

2005-2: Torben J. Andersen: Capital Structure, Environmental Dynamism, Innovation Strategy, and Strategic Risk Management

2005-3: Torben J. Andersen: A Strategic Risk Management Framework for Multinational Enterprise

2005-4: Peter Holdt Christensen: Facilitating Knowledge Sharing: A Conceptual Framework

2005-5 Kirsten Foss \& Nicolai J. Foss: Hands Off! How Organizational Design Can Make Delegation Credible

2005-6 Marjorie A. Lyles, Torben Pedersen \& Bent Petersen: Closing the Knowledge Gap in Foreign Markets - A Learning Perspective

2005-7 Christian Geisler Asmussen, Torben Pedersen \& Bent Petersen: How do we Capture "Global Specialization" when Measuring Firms' Degree of internationalization?

2005-8 Kirsten Foss \& Nicolai J. Foss: Simon on Problem-Solving: Implications for New Organizational Forms

2005-9 Birgitte Grøgaard, Carmine Gioia \& Gabriel R.G. Benito: An Empirical Investigation of the Role of Industry Factors in the Internationalization Patterns of Firms

2005-10 Torben J. Andersen: The Performance and Risk Management Implications of Multinationality: An Industry Perspective

2005-11 Nicolai J. Foss: The Scientific Progress in Strategic Management: The case of the Resource-based view

2005-12 Koen H. Heimeriks: Alliance Capability as a Mediator Between Experience and Alliance Performance: An Empirical Investigation Into the Alliance Capability Development Process

2005-13 Koen H. Heimeriks, Geert Duysters \& Wim Vanhaverbeke: Developing Alliance Capabilities: An Empirical Study

2005-14 JC Spender: Management, Rational or Creative? A Knowledge-Based Discussion

\section{6}

2006-1: Nicolai J. Foss \& Peter G. Klein: The Emergence of the Modern Theory of the Firm

2006-2: Teppo Felin \& Nicolai J. Foss: Individuals and Organizations: Thoughts on a Micro-Foundations Project for Strategic Management and Organizational Analysis

2006-3: Volker Mahnke, Torben Pedersen \& Markus Venzin: Does Knowledge Sharing 
Pay? An MNC Subsidiary Perspective on Knowledge Outflows

2006-4: Torben Pedersen: Determining Factors of Subsidiary Development

2006-5 Ibuki Ishikawa: The Source of Competitive Advantage and Entrepreneurial Judgment in the RBV: Insights from the Austrian School Perspective

2006-6 Nicolai J. Foss \& Ibuki Ishikawa: Towards a Dynamic Resource-Based View: Insights from Austrian Capital and Entrepreneurship Theory

2006-7 Kirsten Foss \& Nicolai J. Foss: Entrepreneurship, Transaction Costs, and Resource Attributes

2006-8 Kirsten Foss, Nicolai J. Foss \& Peter G. Klein: Original and Derived Judgement: An Entrepreneurial Theory of Economic Organization

2006-9 Mia Reinholt: No More Polarization, Please! Towards a More Nuanced Perspective on Motivation in Organizations

2006-10 Angelika Lindstrand, Sara Melen \& Emilia Rovira: Turning social capital into business? A study of Swedish biotech firms' international expansion

2006-11 Christian Geisler Asmussen, Torben Pedersen \& Charles Dhanaraj: Evolution of Subsidiary Competences: Extending the Diamond Network Model

2006-12 John Holt, William R. Purcell, Sidney J. Gray \& Torben Pedersen: Decision Factors Influencing MNEs Regional Headquarters Location Selection Strategies

2006-13 Peter Maskell, Torben Pedersen, Bent Petersen \& Jens Dick-Nielsen: Learning Paths to Offshore Outsourcing - From Cost Reduction to Knowledge Seeking

2006-14 Christian Geisler Asmussen: Local, Regional or Global? Quantifying MNC Geographic Scope

2006-15 Christian Bjørnskov \& Nicolai J. Foss: Economic Freedom and Entrepreneurial Activity: Some Cross-Country Evidence

2006-16 Nicolai J. Foss \& Giampaolo Garzarelli: Institutions as Knowledge Capital: Ludwig M. Lachmann's Interpretative Institutionalism

2006-17 Koen H. Heimriks \& Jeffrey J. Reuer: How to Build Alliance Capabilities

2006-18 Nicolai J. Foss, Peter G. Klein, Yasemin Y. Kor \& Joseph T. Mahoney: Entrepreneurship, Subjectivism, and the Resource - Based View: Towards a New Synthesis

2006-19 Steven Globerman \& Bo B. Nielsen: Equity Versus Non-Equity International Strategic Alliances: The Role of Host Country Governance

\section{7}

2007-1 Peter Abell, Teppo Felin \& Nicolai J. Foss: Building Micro-Foundations for the Routines, Capabilities, and Performance Links 
2007-2 Michael W. Hansen, Torben Pedersen \& Bent Petersen: MNC Strategies and Linkage Effects in Developing Countries

2007-3 Niron Hashai, Christian G. Asmussen, Gabriel R.G. Benito \& Bent Petersen: Predicting the Diversity of Foreign Entry Modes

2007-4 Peter D. Ørberg Jensen \& Torben Pedersen: Whether and What to Offshore?

2007-5 Ram Mudambi \& Torben Pedersen: Agency Theory and Resource Dependency Theory: Complementary Explanations for Subsidiary Power in Multinational Corporations

2007-6 Nicolai J. Foss: Strategic Belief Management

2007-7 Nicolai J. Foss: Theory of Science Perspectives on Strategic Management Research: Debates and a Novel View

2007-8 Dana B. Minbaeva: HRM Practices and Knowledge Transfer in MNCs

2007-9 Nicolai J. Foss: Knowledge Governance in a Dynamic Global Context: The Center for Strategic Management and Globalization at the Copenhagen Business School

2007-10 Paola Gritti \& Nicolai J. Foss: Customer Satisfaction and Competencies: An Econometric Study of an Italian Bank

2007-11 Nicolai J. Foss \& Peter G. Klein: Organizational Governance

2007-12 Torben Juul Andersen \& Bo Bernhard Nielsen: The Effective Ambidextrous Organization: A Model of Integrative Strategy Making Processes.

\section{8}

2008-1 Kirsten Foss \& Nicolai J. Foss: Managerial Authority When Knowledge is Distributed: A Knowledge Governance Perspective

2008-2 Nicolai J. Foss: Human Capital and Transaction Cost Economics.

2008-3 Nicolai J. Foss \& Peter G. Klein: Entrepreneurship and Heterogeneous Capital.

2008-4 Nicolai J. Foss \& Peter G. Klein: The Need for an Entrepreneurial Theory of the Firm.

2008-5 Nicolai J. Foss \& Peter G. Klein: Entrepreneurship: From Opportunity Discovery to Judgment.

2008-6 Mie Harder: How do Rewards and Management Styles Influence the Motivation to Share Knowledge?

2008-7 Bent Petersen, Lawrence S. Welch \& Gabriel R.G. Benito: Managing the Internalisation Process - A Theoretical Perspective.

2008-8 Torben Juul Andersen: Multinational Performance and Risk Management Effects: Capital Structure Contingencies. 
2008-9 Bo Bernard Nielsen: Strategic Fit and the Role of Contractual and Procedural Governance in Alliances: A Dynamic Perspective.

2008-10 Line Gry Knudsen \& Bo Bernhard Nielsen: Collaborative Capability in R\&D Alliances: Exploring the Link between Organizational and Individual level Factors.

2008-11 Torben Juul Andersen \& Mahesh P. Joshi: Strategic Orientations of Internationalizing Firms: A Comparative Analysis of Firms Operating in Technology Intensive and Common Goods Industries.

2008-12 Dana Minbaeva: HRM Practices Affecting Extrinsic and Intrinsic Motivation of Knowledge Receivers and their Effect on Intra-MNC Knowledge Transfer.

2008-13 Steen E. Navrbjerg \& Dana Minbaeva: HRM and IR in Multinational Corporations: Uneasy Bedfellows?

2008-14 Kirsten Foss \& Nicolai J. Foss: Hayekian Knowledge Problems in Organizational Theory.

2008-15 Torben Juul Andersen: Multinational Performance Relationships and Industry Context.

2008-16 Larissa Rabbiosi: The Impact of Subsidiary Autonomy on MNE Knowledge Transfer: Resolving the Debate.

2008-17 Line Gry Knudsen \& Bo Bernhard Nielsen: Organizational and Individual Level Antecedents of Procedural Governance in Knowledge Sharing Alliances.

2008-18 Kirsten Foss \& Nicolai J. Foss: Understanding Opportunity Discovery and Sustainable Advantage: The Role of Transaction Costs and Property Rights.

2008-19 Teppo Felin \& Nicolai J. Foss: Social Reality, The Boundaries of Self-fulfilling Prophecy, and Economics.

2008-20 Yves Dos, Nicolai J. Foss \& José Santos: A Knowledge System Approach to the Multinational Company: Conceptual Grounding and Implications for Research

2008-21 Sabina Nielsen \& Bo Bernhard Nielsen: Why do Firms Employ foreigners on Their Top Management Teams? A Multi-Level Exploration of Individual and Firm Level Antecedents

2008-22 Nicolai J. Foss: Review of Anders Christian Hansen's “Uden for hovedstrømmen - Alternative strømninger i økonomisk teori"

2008-23 Nicolai J. Foss: Knowledge, Economic Organization, and Property Rights

2008-24 Sjoerd Beugelsdijk, Torben Pedersen \& Bent Petersen: Is There a Trend Towards Global Value Chain Specialization? - An Examination of Cross Border Sales of US Foreign Affiliates 
2008-25 Vikas Kumar, Torben Pedersen \& Alessandro Zattoni: The performance of business group firms during institutional transition: A longtitudinal study of Indian firms

2008-26 Sabina Nielsen \& Bo B. Nielsen: The effects of TMT and Board Nationality Diversity and Compensation on Firm Performance

2008-27 Bo B. Nielsen \& Sabina Nielsen: International Diversification Strategy and Firm Performance: A Multi-Level Analysis of Firm and Home Country Effects

\section{9}

2009-1 Nicolai J. Foss: Alternative Research Strategies in the Knowledge Movement: From Macro Bias to Micro-Foundations and Multi-Level Explanation

2009-2 Nicolai J. Foss \& Peter G. Klein: Entrepreneurial Alertness and Opportunity Discovery: Origins, Attributes, Critique

2009-3 Nicolai J. Foss \& Dana B. Minbaeva: Governing Knowledge: The Strategic Human Resource Management Dimension

2009-4 Nils Stieglitz \& Nicolai J. Foss: Opportunities and New Business Models: Transaction Cost and Property Rights Perspectives on Entrepreneurships

2009-5 Torben Pedersen: Vestas Wind Systems A/S: Exploiting Global R\&D Synergies

2009-6 Rajshree Agarwal, Jay B. Barney, Nicolai J. Foss \& Peter G. Klein: Heterogeneous Resources and the Financial Crisis: Implications of Strategic Management Theory

2009-7 Jasper J. Hotho: A Measure of Comparative Institutional Distance

2009-8 Bo B. Nielsen \& Sabina Nielsen: The Impact of Top Management Team Nationality Diversity and International Experience on Foreign Entry Mode

2009-9 Teppo Felin \& Nicolai Juul Foss: Experience and Repetition as Antecedents of Organizational Routines and Capabilities: A Critique of Behaviorist and Empiricist Approaches

2009-10 Henk W. Volberda, Nicolai J. Foss \& Marjorie E. Lyles: Absorbing the Concept of Absorptive Capacity: How To Realize Its Potential in the Organization Field

2009-11 Jan Stentoft Arlbjørn, Brian Vejrum Wæhrens, John Johansen \& Torben Pedersen: Produktion i Danmark eller offshoring/outsourcing: Ledelsesmæssige udfordringer 


\section{0}

2010-1 Dana B. Minbaeva, Kristiina Mäkelä \& Larissa Rabbiosi: Explaining Intraorganizational Knowledge Transfer at the Individual Level

2010-2 Dana B.Minbaeva \& Torben Pedersen: Governing Individual Knowledge Sharing Behavior

2010-3 Nicolai J. Foss \& Peter G. Klein: Alertness, Judgment, and the Antecedents of Entrepreneurship

2010-4 Nicolai J.Foss \& Joseph T.Mahoney: Exploring Knowledge Governance

2010-5 Jasper J. Hotho, Florian Becker-Ritterspach \& Ayse Saka-Helmhout: Enriching Absorptive Capacity Through Social Interaction

2010-6 Nicolai J. Foss \& Bo B. Nielsen: Researching Collaborative Advantage: Some Conceptual and Multi-level Issues

2010-7 Nicolai J. Foss \& Nils Stieglitz: Modern Resource-Based Theory(ies)

2010-8 Christian Bjørnskov \& Nicolai J. Foss: Do Economic Freedom and Entrepreneurship Impact Total Factor Productivity?

2010-9 Gabriel R.G. Benito, Bent Petersen \& Lawrence S. Welch: Mode Combinations and International Operations: Theoretical Issues and an Empirical Investigation

\section{1}

2011-1 Peter D. Ørberg Jensen \& Bent Petersen: Human Asset Internalization and Global Sourcing of Services - A Strategic Management Analysis on Activity-level

2011-2 Mie Harder: Management Innovation Capabilities: A Typology and Propositions for Management Innovation Research

2011-3 Mie Harder: Internal Antecedents of Management Innovation: The effect of diagnostic capability and implementation capability 
2011-4 Mie Harder: Explaining Management Innovation Pervasiveness: The Role of Internal Antecedents

2011-5 Mie Harder: Internal Determinants of Product Innovation and Management Innovation: The Effect of Diagnostic Capability and Implementation Capability

2011-6 Nicolai J. Foss, Peter G. Klein \& Per L. Bylund: Entrepreneurship and the Economics of the Firm

2011-7 Nicolai J. Foss \& Jacob Lyngsie: The Emerging Strategic Entrepreneurship Field: Origins, Key Tenets and Research Gaps

2011-8 Nicolai J. Foss: Entrepreneurship in the Context of the Resource-based View of the Firm

2011-9 Bent Petersen, Gabriel R.G. Benito, Olesya Dovgan \& Lawrence Welch: Offshore outsourcing: A dynamic, operation mode perspective

2011-10 Bent Petersen, Gabriel R. G. Benito \& Lawrence Welch: Dynamics of Foreign Operation Modes and their Combinations: Insights for International Strategic Management

2011-11 Nicolai J. Foss: Teams, Team Motivation, and the Theory of the Firm

2011-12 Nicolai J. Foss: Knowledge Governance: Meaning, Nature, Origins, and Implications

2011-13 Nicolai J. Foss, Kirsten Foss \& Phillip C. Nell: MNC Organizational Form and Subsidiary Motivation Problems: Controlling Intervention Hazards in the Network MNC

2011-14 Kåre Moberg: Evaluating Content Dimensions in Entrepreneurship Education

\section{2}

2012-1 Nicolai J. Foss, Nicholas Argyres, Teppo Felin \& Todd Zenger: The Organizational Economics of Organizational Capability and Heterogeneity: A Research Agenda 
2012-2 Torben J. Andersen, Carina Antonia Hallin \& Sigbjørn Tveterås: A Prediction Contest: The Sensing of Frontline Employees Against Executive Expectations

2012-3 Peter G. Klein, Jay B. Barney \& Nicolai J. Foss: Strategic Entrepreneurship

2012-4 Kåre Moberg: The Impact of Entrepreneurship Education and Project-based Education on Students' Personal Development and Entrepreneurial Intentions at the Lower Levels of the Educational System: Too Much of Two Good Things?

2012-5 Keld Laursen \& Nicolai J. Foss: Human Resource Management Practices and Innovation

2012-6 Kåre Moberg: An Entrepreneurial Self-Efficacy Scale with a Neutral Wording

\section{3}

2013-1

Nicolai J. Foss, Diego Stea: The Principal's Theory of Mind: The Role of Mentalizing for Reward Design and Management in Principal-Agent Relations

2013-2 Dana Minbaeva, Chansoo Park \& Ilan Vertinsky: The Influence of Foreign Partners' Disseminative Capacities on Knowledge Transfers to International Joint Ventures

2013-3

Nicolai J. Foss \& Peter G. Klein: Hayek and Organizational Studies

2013-4 Kåre Moberg, Lene Vestergaard, Casper Jørgensen, Elisabeth Markussen \& Sose Hakverdyan: How to Assess the Development of Entrepreneurship Education at University Level - the Case of Denmark

2013-5 Nicolai J. Foss \& Siegwart Lindenberg: Micro-Foundations For Strategy: A Goal-Framing Perspective on the Drivers of Value Creation 
2013-6 Nicolai J. Foss, Jacob Lyngsie \& Shaker A. Zahra: The Role of External Knowledge Sources and Organizational Design in the Process of Opportunity Exploitation

2013-7 Stefan Linder \& Nicolai J. Foss: Agency Theory.

2013-8 Nicolai J. Foss, Peter G. Klein, Stefan Linder: Organizations and Markets

2013-9 Nicolai J. Foss: Towards an Organizational Economics of Heterogeneous Capabilities 